\title{
Modeling and simulation to predict variation of void ration and permeability influence on E-coli transport in heterogeneous sand gravel depositions
}

\begin{abstract}
This study monitored heterogeneous deposition of void ratio in predominant sand gravel depositions, several studies had been done on transport system with relation to depth of the formation, but the study centered more on time of transport in relation to heterogeneous void ratio and permeability of sand gravel formation, the time of transport were subjected to determine the rate of transport to the Phreatic depositions, fluctuation and exponential phase of transport were observed in the study area, depth of transport were slightly evaluated in the study, but the focus of the study is more on time influenced by heterogeneous void ratio on sand gravel depositions, simulation generated predictive values that were validated with experimental values and both parameters express favorable fits for model validation, the study provide platform to monitor time of transport influenced by heterogeneous void ratio in predominant sand grave depositions. Experts will definitely use the concept to monitor time of transport of E-Coli in sand gravel formation.
\end{abstract}

Keywords: modeling variation void ratio, permeability, E-Coli, transport and sand gravel formation
Volume 2 Issue 5 - 2018

\author{
Eluozo SN,' Afiibor BB² \\ 'Department of Civil Engineering, Gregory University Uturu \\ (GUU), Nigeria \\ ${ }^{2}$ Department of Statistics Federal Polytechnic, Nigeria
}

Correspondence: Eluozo SN, Department of Civil Engineering, Gregory University Uturu (GUU), Abia State of Nigeria, Nigeria, Email Soloeluozo2013@hotmail.com

Received: August 31, 2018 | Published: October 08, 2018

\section{Introduction}

The behaviour of soil base on evaluation tools known as (SWAT) $)^{1,2}$ was effectively applied to simulate river flow micronutrient were found from evaluation of the Rivers, ${ }^{3}$ and E. coli fluxes. ${ }^{4-6}$ The integration of this model was done in landscape which also includes in-stream microbial processes, this concept was thoroughly applied in other to simulate management scenarios in degradation of contamination. ${ }^{2,3,7}$ The programme called SWAT permit modeling of bacteria fate and transport. even though calibration of the model for faecal fluxes seems more difficult compare to flow, it may be due to the paucity of data and inadequate understanding of E. coli biophysical process, this concept has definitely signify most important breakthrough on approximation E. coli fluxes. ${ }^{4,8}$ The system of developing modeling in regional degree has been an adopted concept in the past years by Lazure and Dumas, ${ }^{9}$ this concept was to explain currents, dilution and transport im most parts of the French coast. In recent times, it was observed that water quality variations have been realizeed, this was observed in some particular faecal contamination through bathing and shellfish harvesting areas. ${ }^{7-9}$ These concept currently applied models is to manage the impact of wastewater on the sea water. ${ }^{10}$ Expressing such knowledge has been applied to monitor the system daily flows that are simulated with a watershed model as an input into another hydrodynamic model to assess daily bacterial concentrations in estuaries. ${ }^{11,12}$ These the two conceptual model applications are used to monitor microbiological contamination in an estuary, which is crucial for coastal management.

\section{Theoretical background}

$$
V \Phi \frac{\partial c}{\partial t}=K V_{t} \frac{\partial^{2} c}{\partial x^{2}}-K_{d} \frac{\partial c}{\partial x}
$$

Nomenclature

\section{$\mathrm{C}=$ E. Coli Concentration}

$$
\begin{array}{ll}
\mathrm{K} & =\text { Permeability } \\
\mathrm{V} & =\text { Velocity } \\
\Phi & =\text { Porosity } \\
\mathrm{K}_{\mathrm{d}} & =\text { Decay Rate } \\
\mathrm{x} & =\text { Depth } \\
\mathrm{T} & =\text { Time } \\
\text { Let } \mathrm{C} & =\mathrm{TX}
\end{array}
$$

Applying Bernoulli's method of separation of variables

$$
\begin{aligned}
& V \Phi \frac{T^{1}}{T}=K V_{t} X^{11}-K_{d} X^{1}=\beta^{2} \\
& V \Phi \frac{T^{1}}{T}=\beta^{2} \\
& K V_{t} X^{11}-K_{d} X^{1}-\beta^{2} X=0 \\
& \text { From } T=a \ell \frac{\beta^{2}}{K V_{t}} t
\end{aligned}
$$

From (4), the auxiliary equation is

$$
\begin{aligned}
& K V_{t} M^{2}-K_{d} M-\beta^{2}=0 \\
& M=\frac{K_{d} \pm \sqrt{K_{d}^{2}+4 K V_{t} \beta^{2}}}{2 V \Phi}
\end{aligned}
$$

Hence, we have

$X=A \operatorname{Cos} M x+B \operatorname{Sin} M x$ 
Combining (3) and (4), we have: -

$$
C(x, t)=a \ell \frac{\beta^{2}}{V \Phi} t[A \operatorname{Cos} M x+B \operatorname{Sin} M x]
$$

Subject equation (8) to boundary condition

at $\quad x=0 \quad c=0$ Yield: -

$0=a A$

i.e. $C(x, t)=a \ell \frac{\beta^{2}}{V \Phi} t[A \operatorname{Cos} M x+B \operatorname{Sin} M x]$

$\frac{\partial c}{\partial x}=C_{o} \frac{\beta^{2}}{V \Phi} t[-A M \operatorname{Sin} M x+B M \operatorname{Cos} M x]$

At $x=0, \frac{\partial c}{\partial x}=0$

$$
o=C_{o} \frac{\beta^{2}}{V \Phi} t(\operatorname{Cos} M x)
$$

At $x=L, \frac{\partial c}{\partial L}=0$ yields: -

$$
\begin{aligned}
& o=C_{O} \frac{\beta^{2}}{V \Phi} t \text { [-AMSinML] } \\
& C_{O} \frac{\beta^{2}}{\ell \Phi \Phi} t \neq 0 \\
& A M \operatorname{Sin} L=0=n \pi, n=1,2,3 \\
& M L=n \pi \quad m=\frac{n \pi}{L} \\
& C(x, t)=\operatorname{Co} \ell \frac{\beta^{2}}{V \Phi} t\left[\operatorname{Cos} \frac{M \pi}{L} x\right] \\
& \text { If } x=V \cdot t
\end{aligned}
$$

$$
C(x, t)=\operatorname{Co} \frac{\beta^{2}}{V \Phi} t\left[\operatorname{Cos} \frac{M \pi}{L} V \cdot t\right]
$$

$$
\text { If } t=\frac{d}{v}
$$

$$
C(x, t)=\operatorname{Co\ell } \frac{\beta^{2}}{V \Phi} t\left[\operatorname{Cos} \frac{M \pi}{L} \frac{d}{v}\right]
$$

\section{Materials and method}

Standard laboratory experiment where performed to monitor the concentration of E-Coli transport at different formation. The soil deposition of the strata was collected in sequences based on the structural deposition at different locations. The samples collected at different locations generated variations at different depth producing different migration of $E$-Coli concentration through pressure flow at the lower end of the column. The experimental result are applied and compared with the theoretical values for model validation.

\section{Results and discussion}

Results are presented in tables and figures including graphical representation of E-Coli concentration. Figure 1 express gradual increase of the predictive $E$-Coli concentration from ten to forty days and suddenly experienced decrease with increase in time to lowest rate concentration recorded at one hundred and twenty days, while the experimental values gradual decrease from the optimum values recorded at ten to the lowest concentration observed at the same period, Figure 2 predictive values experienced fluctuation where the optimum values was observed at ninety day and final decrease down to the lowest rate of concentration recorded at one twenty days, while the experimental values maintained fluctuation but at different time to the lowest concentration recorded at the same time. Figure 3 observed similar condition but at different time, fluctuation were experienced from ten to two hundred days, where the lowest concentration were observed, while that of experimental values maintained similar condition, but experience higher concentration compared to that of the predictive. Figure 4 developed an exponential phase of the system were the optimum values were recorded sixty metres, while the experimental values maintained the same trend to the optimum parameters recorded at the same depth. Figure 5 predictive maintained linear increase with increase in depth to the optimum values observed at sixty metres, while that of the experimental values experienced vacillation from nine to forty days and linearly increase to the optimum at thirty nine days, Figure 6 observed gradual increase and suddenly experience decrease to lowest rate of concentration. While that of the experimental values increase in similar condition to the optimum values at hundred and fifty days, but suddenly experienced slight decrease between hundred and sixty to two hundred days, while Figure 7 gradually increase with depth to the optimum values recorded at thirty six metres and suddenly experiences decrease to the lowest concentration recorded at sixty metres, while that of the experimental values maintained the same trend of concentration to the lowest depth at sixty metres. Figure 8 predictive and experimental values developed fluctuation from twenty four to sixty metres, Figure 9 predictive observed different concentration in migration, and both parameters observed gradual increase to the optimum values recorded at two hundred days (Tables 1-10).

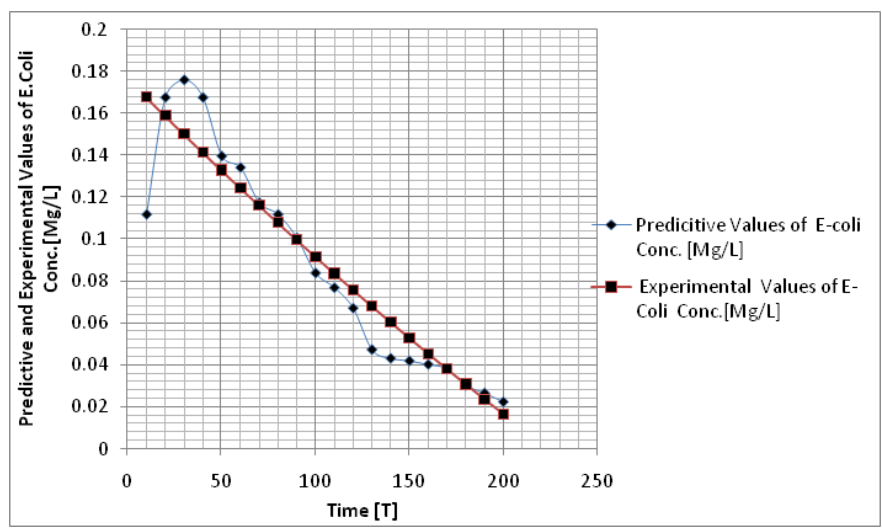

Figure I Predictive and experimental values of E-Coli concentration at different depth.

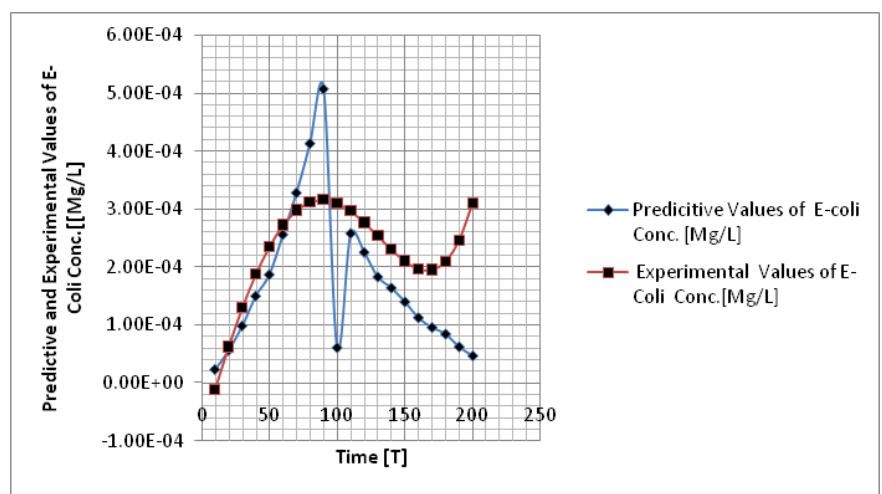

Figure 2 Predictive and experimental values of E-Coli concentration at different time. 


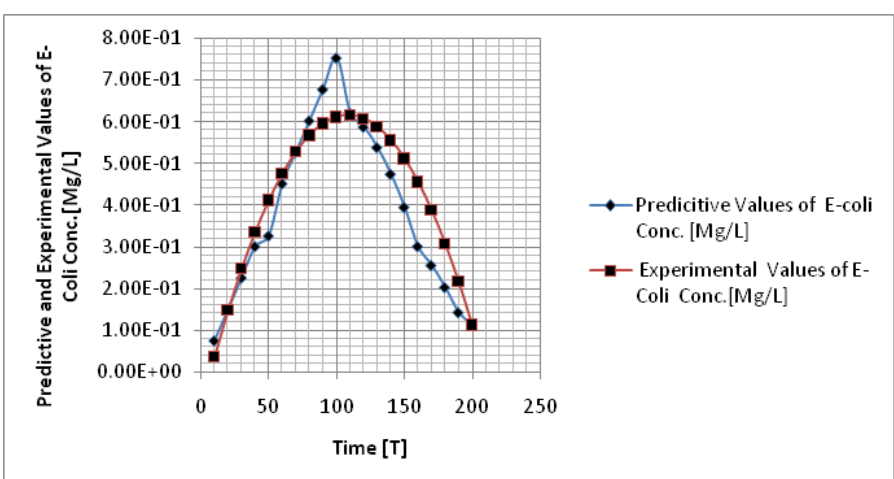

Figure 3 Predictive and experimental values of E-Coli concentration at different time.

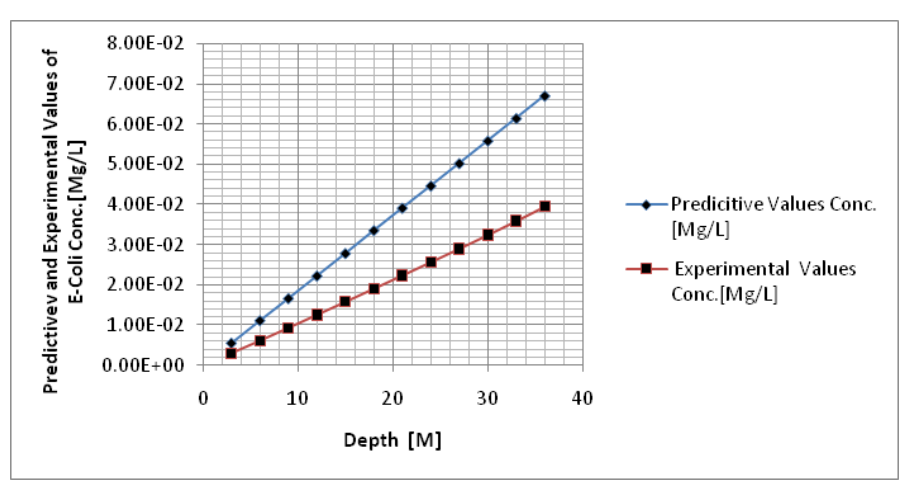

Figure 4 Predictive and experimental values of E-Coli concentration at different depth.

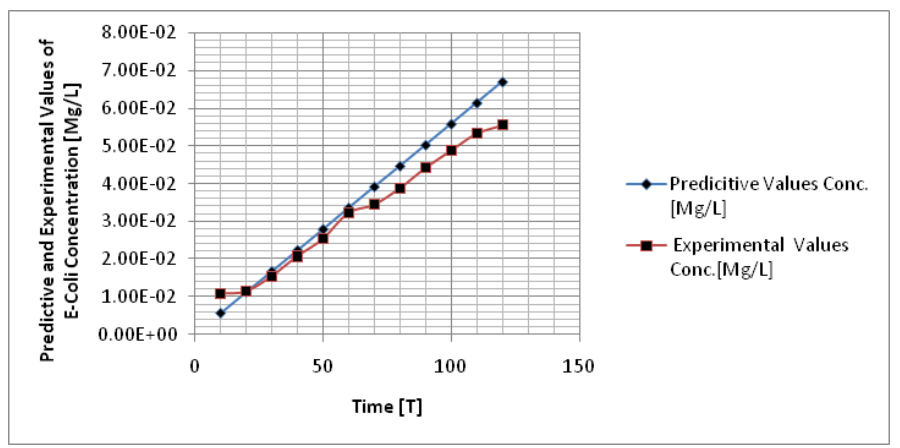

Figure 5 Predictive and experimental values of E-Coli concentration at different time.

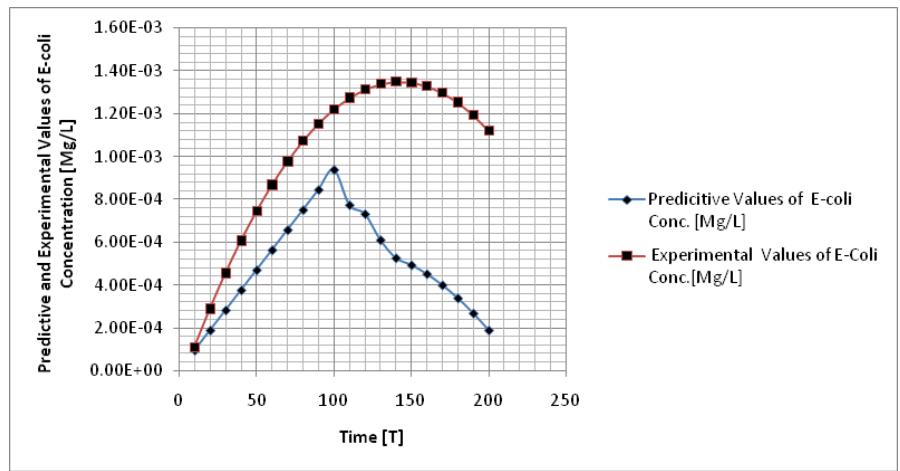

Figure 6 Predictive and experimental values of E-Coli concentration at different time.

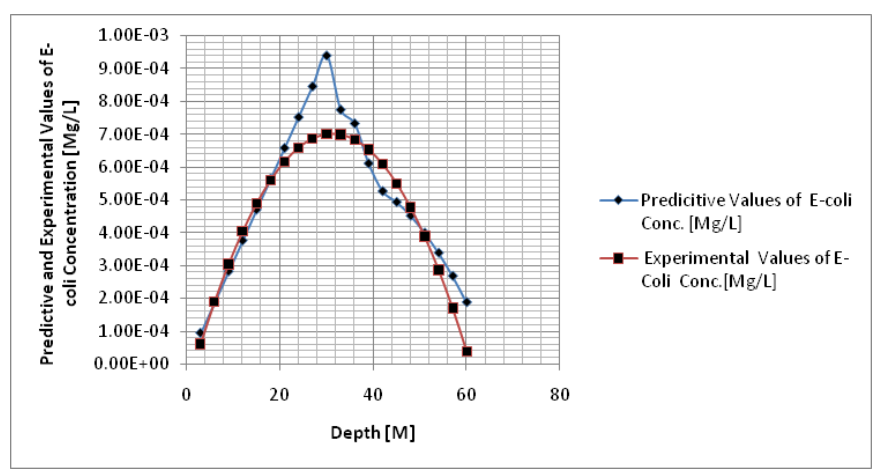

Figure 7 Predictive and experimental values of E-Coli concentration at different depth.

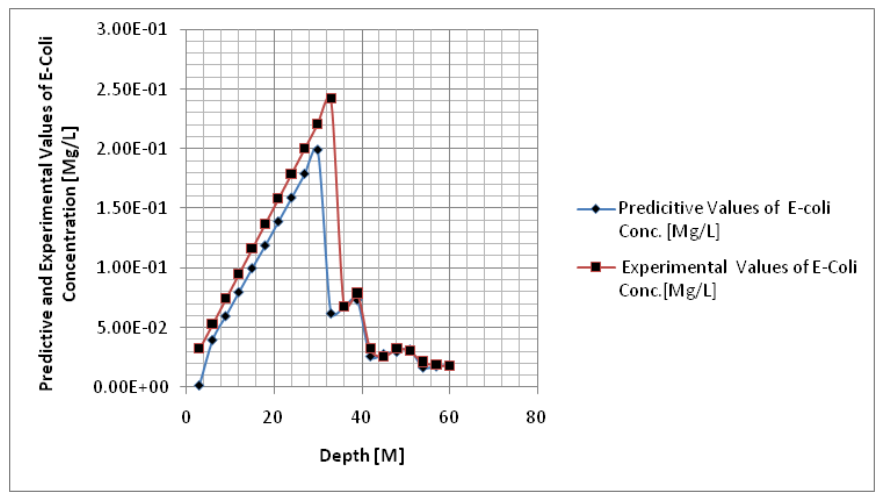

Figure 8 Predictive and experimental values of E-Coli Concentration at different depth.

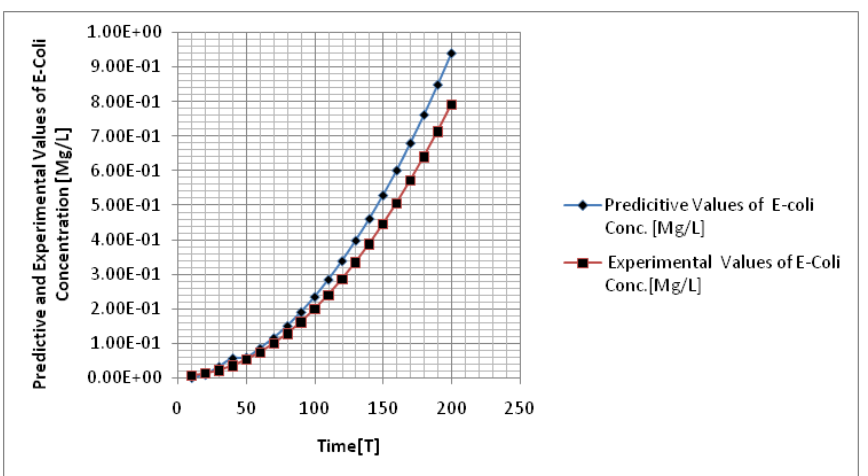

Figure 9 Predictive and experimental values of E-Coli concentration at different depth.

Table I Predictive and experimental values of E-coli concentration at different time

\begin{tabular}{lll}
\hline Time [T] & $\begin{array}{l}\text { Predictive values of } \\
\text { E-coli conc. }[\mathrm{Mg} / \mathrm{L}]\end{array}$ & $\begin{array}{l}\text { Experimental values } \\
\text { of E-Coli conc. [Mg/L] }\end{array}$ \\
\hline 10 & 0.1119 & 0.16765 \\
20 & 0.1678 & 0.1588 \\
30 & 0.1762 & 0.15005 \\
40 & 0.1678 & 0.1414 \\
50 & 0.1398 & 0.13285 \\
60 & 0.1343 & 0.1244 \\
\hline
\end{tabular}


Table Continued...

\begin{tabular}{lll}
\hline Time [T] & $\begin{array}{l}\text { Predictive values of } \\
\text { E-coli conc. [Mg/L] }\end{array}$ & $\begin{array}{l}\text { Experimental values } \\
\text { of E-Coli conc.[Mg/L] }\end{array}$ \\
\hline 70 & 0.1175 & 0.11605 \\
80 & 0.1119 & 0.1078 \\
90 & 0.1007 & 0.09965 \\
100 & 0.0839 & 0.0916 \\
110 & 0.0769 & 0.08365 \\
120 & 0.0671 & 0.0758 \\
130 & 0.0473 & 0.06805 \\
140 & 0.0431 & 0.0604 \\
150 & 0.0419 & 0.05285 \\
160 & 0.0402 & 0.0454 \\
170 & 0.0381 & 0.03805 \\
180 & 0.0302 & 0.0308 \\
190 & 0.0265 & 0.02365 \\
200 & 0.0223 & 0.0166 \\
\hline
\end{tabular}

Table 2 Predictive and experimental values of E-coli concentration at different time

\begin{tabular}{lll}
\hline Time $[\mathrm{T}]$ & $\begin{array}{l}\text { Predictive values of } \\
\text { E-coli conc. }[\mathrm{Mg} / \mathrm{L}]\end{array}$ & $\begin{array}{l}\text { Experimental values of } \\
\text { E-Coli conc.[Mg/L] }\end{array}$ \\
\hline 10 & $2.34 \mathrm{E}-05$ & -0.00001148 \\
20 & $5.63 \mathrm{E}-05$ & 0.00006232 \\
30 & $9.86 \mathrm{E}-05$ & 0.00012912 \\
40 & $1.50 \mathrm{E}-04$ & 0.00018712 \\
50 & $1.87 \mathrm{E}-04$ & 0.000235 \\
60 & $2.56 \mathrm{E}-04$ & 0.00027192 \\
70 & $3.28 \mathrm{E}-04$ & 0.00029752 \\
80 & $4.13 \mathrm{E}-04$ & 0.00031192 \\
90 & $5.07 \mathrm{E}-04$ & 0.00031572 \\
100 & $6.10 \mathrm{E}-05$ & 0.00031 \\
110 & $2.58 \mathrm{E}-04$ & 0.00029632 \\
120 & $2.25 \mathrm{E}-04$ & 0.00027672 \\
130 & $1.83 \mathrm{E}-04$ & 0.00025372 \\
140 & $1.64 \mathrm{E}-04$ & 0.00023032 \\
150 & $1.40 \mathrm{E}-04$ & 0.00021 \\
160 & $1.13 \mathrm{E}-04$ & 0.00019672 \\
170 & $9.58 \mathrm{E}-05$ & 0.00019492 \\
180 & $8.45 \mathrm{E}-05$ & 0.00020952 \\
190 & $6.25 \mathrm{E}-05$ & 0.00024592 \\
200 & $4.70 \mathrm{E}-05$ & 0.00031 \\
\hline
\end{tabular}

Table 3 Predictive and experimental values of E-coli concentration at different time

\begin{tabular}{|c|c|c|}
\hline Time $[\mathrm{T}]$ & $\begin{array}{l}\text { Predictive values of } \\
\text { E-coli conc. [Mg/L] }\end{array}$ & $\begin{array}{l}\text { Experimental values } \\
\text { of } E \text {-Coli conc. [Mg/L] }\end{array}$ \\
\hline 10 & 7.54E-02 & 0.036 \\
\hline 20 & I.5IE-0| & 0.148 \\
\hline 30 & $2.26 \mathrm{E}-0 \mathrm{I}$ & 0.248 \\
\hline 40 & $3.02 \mathrm{E}-0 \mathrm{I}$ & 0.336 \\
\hline 50 & 3.27E-0I & 0.412 \\
\hline 60 & 4.52E-0I & 0.476 \\
\hline 70 & $5.28 \mathrm{E}-0 \mathrm{I}$ & 0.528 \\
\hline 80 & $6.03 \mathrm{E}-0 \mathrm{I}$ & 0.568 \\
\hline 90 & 6.79E-0I & 0.596 \\
\hline 100 & 7.54E-0I & 0.612 \\
\hline 110 & $6.22 \mathrm{E}-0 \mathrm{I}$ & 0.616 \\
\hline 120 & $5.88 \mathrm{E}-0 \mathrm{I}$ & 0.608 \\
\hline 130 & 5.39E-0I & 0.588 \\
\hline 140 & 4.75E-0I & 0.556 \\
\hline 150 & $3.96 \mathrm{E}-0 \mathrm{I}$ & 0.512 \\
\hline 160 & $3.02 \mathrm{E}-0 \mathrm{I}$ & 0.456 \\
\hline 170 & $2.56 \mathrm{E}-0 \mathrm{I}$ & 0.388 \\
\hline 180 & 2.04E-0I & 0.308 \\
\hline 190 & I.43E-0I & 0.216 \\
\hline 200 & $1.13 \mathrm{E}-0 \mid$ & 0.112 \\
\hline
\end{tabular}

Table 4 Predictive and experimental values of E-coli concentration at different depth

\begin{tabular}{lll}
\hline Depth [M] & $\begin{array}{l}\text { Predictive values } \\
\text { conc. }[\mathrm{Mg} / \mathrm{L}]\end{array}$ & $\begin{array}{l}\text { Experimental } \\
\text { values conc. [Mg/L] }\end{array}$ \\
\hline 3 & $5.59 \mathrm{E}-03$ & $3.05 \mathrm{E}-03$ \\
6 & $1.12 \mathrm{E}-02$ & $6.18 \mathrm{E}-03$ \\
9 & $1.67 \mathrm{E}-02$ & $9.36 \mathrm{E}-03$ \\
12 & $2.23 \mathrm{E}-02$ & $1.26 \mathrm{E}-02$ \\
15 & $2.79 \mathrm{E}-02$ & $1.58 \mathrm{E}-02$ \\
18 & $3.36 \mathrm{E}-02$ & $1.91 \mathrm{E}-02$ \\
21 & $3.92 \mathrm{E}-02$ & $2.24 \mathrm{E}-02$ \\
24 & $4.47 \mathrm{E}-02$ & $2.57 \mathrm{E}-02$ \\
27 & $5.03 \mathrm{E}-02$ & $2.90 \mathrm{E}-02$ \\
30 & $5.59 \mathrm{E}-02$ & $3.24 \mathrm{E}-02$ \\
33 & $6.15 \mathrm{E}-02$ & $3.59 \mathrm{E}-02$ \\
36 & $6.7 \mathrm{IE}-02$ & $3.95 \mathrm{E}-02$ \\
\hline
\end{tabular}


Table 5 Predictive and experimental values of E-coli concentration at different depth

\begin{tabular}{lll}
\hline Time $[\mathrm{T}]$ & $\begin{array}{l}\text { Predictive values } \\
\text { conc. }[\mathrm{Mg} / \mathrm{L}]\end{array}$ & $\begin{array}{l}\text { Experimental } \\
\text { values conc.[Mg/L] }\end{array}$ \\
\hline 10 & $5.59 \mathrm{E}-03$ & $1.10 \mathrm{E}-02$ \\
20 & $1.12 \mathrm{E}-02$ & $1.15 \mathrm{E}-02$ \\
30 & $1.67 \mathrm{E}-02$ & $1.55 \mathrm{E}-02$ \\
40 & $2.23 \mathrm{E}-02$ & $2.08 \mathrm{E}-02$ \\
50 & $2.79 \mathrm{E}-02$ & $2.54 \mathrm{E}-02$ \\
60 & $3.36 \mathrm{E}-02$ & $3.23 \mathrm{E}-02$ \\
70 & $3.92 \mathrm{E}-02$ & $3.45 \mathrm{E}-02$ \\
80 & $4.47 \mathrm{E}-02$ & $3.88 \mathrm{E}-02$ \\
90 & $5.03 \mathrm{E}-02$ & $4.42 \mathrm{E}-02$ \\
100 & $5.59 \mathrm{E}-02$ & $4.88 \mathrm{E}-02$ \\
110 & $6.15 \mathrm{E}-02$ & $5.33 \mathrm{E}-02$ \\
120 & $6.71 \mathrm{E}-02$ & $5.55 \mathrm{E}-02$ \\
\hline
\end{tabular}

Table 6 Predictive and experimental values of e-coli concentration at different depth

\begin{tabular}{|c|c|c|}
\hline Time $[\mathrm{T}]$ & $\begin{array}{l}\text { Predictive values of } \\
\text { E-coli conc. }[\mathrm{Mg} / \mathrm{L}]\end{array}$ & $\begin{array}{l}\text { Experimental values } \\
\text { of } E-C \text { - oli conc. }[\mathrm{Mg} / \mathrm{L}]\end{array}$ \\
\hline 10 & $9.39 \mathrm{E}-05$ & 0.000113 \\
\hline 20 & I.88E-04 & 0.000292 \\
\hline 30 & $2.82 \mathrm{E}-04$ & 0.000457 \\
\hline 40 & $3.76 \mathrm{E}-04$ & 0.000608 \\
\hline 50 & $4.70 \mathrm{E}-04$ & 0.000745 \\
\hline 60 & $5.63 \mathrm{E}-04$ & 0.000868 \\
\hline 70 & $6.57 \mathrm{E}-04$ & 0.000977 \\
\hline 80 & $7.5 \mathrm{IE}-04$ & 0.001072 \\
\hline 90 & $8.45 \mathrm{E}-04$ & 0.001153 \\
\hline 100 & $9.39 \mathrm{E}-04$ & 0.00122 \\
\hline 110 & 7.74E-04 & 0.001273 \\
\hline 120 & 7.32E-04 & 0.001312 \\
\hline 130 & 6. $10 \mathrm{E}-04$ & 0.001337 \\
\hline 140 & $5.26 \mathrm{E}-04$ & 0.001348 \\
\hline 150 & $4.93 \mathrm{E}-04$ & 0.001345 \\
\hline 160 & $4.5 \mathrm{IE}-04$ & $0.00 \mid 328$ \\
\hline 170 & 3.99E-04 & 0.001297 \\
\hline 180 & $3.38 \mathrm{E}-04$ & 0.001252 \\
\hline 190 & $2.68 \mathrm{E}-04$ & 0.001193 \\
\hline 200 & I.88E-04 & 0.00112 \\
\hline
\end{tabular}

Table 7 Predictive and Experimental Values of E-Coli Concentration at Different Depth

\begin{tabular}{lll}
\hline Depth [M] & $\begin{array}{l}\text { Predictive values of } \\
\text { E-coli conc. [Mg/L] }\end{array}$ & $\begin{array}{l}\text { Experimental values of } \\
\text { E-Coli conc.[Mg/L] }\end{array}$ \\
\hline 3 & $9.39 \mathrm{E}-05$ & $6.28 \mathrm{E}-05$ \\
6 & $1.88 \mathrm{E}-04$ & $1.91 \mathrm{E}-04$ \\
9 & $2.82 \mathrm{E}-04$ & $3.05 \mathrm{E}-04$ \\
12 & $3.76 \mathrm{E}-04$ & $4.05 \mathrm{E}-04$ \\
15 & $4.70 \mathrm{E}-04$ & $4.90 \mathrm{E}-04$ \\
18 & $5.63 \mathrm{E}-04$ & $5.61 \mathrm{E}-04$ \\
21 & $6.57 \mathrm{E}-04$ & $6.17 \mathrm{E}-04$ \\
24 & $7.5 \mathrm{IE}-04$ & $6.59 \mathrm{E}-04$ \\
27 & $8.45 \mathrm{E}-04$ & $6.87 \mathrm{E}-04$ \\
30 & $9.39 \mathrm{E}-04$ & $7.00 \mathrm{E}-04$ \\
33 & $7.74 \mathrm{E}-04$ & $6.99 \mathrm{E}-04$ \\
36 & $7.32 \mathrm{E}-04$ & $6.83 \mathrm{E}-04$ \\
39 & $6.10 \mathrm{E}-04$ & $6.53 \mathrm{E}-04$ \\
42 & $5.26 \mathrm{E}-04$ & $6.09 \mathrm{E}-04$ \\
45 & $4.93 \mathrm{E}-04$ & $5.50 \mathrm{E}-04$ \\
48 & $4.5 \mathrm{IE}-04$ & $4.77 \mathrm{E}-04$ \\
51 & $3.99 \mathrm{E}-04$ & $3.89 \mathrm{E}-04$ \\
54 & $3.38 \mathrm{E}-04$ & $2.87 \mathrm{E}-04$ \\
57 & $2.68 \mathrm{E}-04$ & $1.7 \mathrm{IE}-04$ \\
60 & $1.88 \mathrm{E}-04$ & $4.00 \mathrm{E}-05$ \\
\hline
\end{tabular}

Table 8 Predictive and experimental values of E-Coli concentration at different depth

\begin{tabular}{lll}
\hline Depth [M] & $\begin{array}{l}\text { Predictive values of } \\
\text { E-coli conc. [Mg/L] }\end{array}$ & $\begin{array}{c}\text { Experimental values of } \\
\text { E-Coli conc. [Mg/L] }\end{array}$ \\
\hline 3 & $1.99 \mathrm{E}-03$ & $3.20 \mathrm{E}-02$ \\
6 & $3.99 \mathrm{E}-02$ & $5.30 \mathrm{E}-02$ \\
9 & $5.99 \mathrm{E}-02$ & $7.40 \mathrm{E}-02$ \\
12 & $7.99 \mathrm{E}-02$ & $9.50 \mathrm{E}-02$ \\
15 & $9.99 \mathrm{E}-02$ & $1.16 \mathrm{E}-01$ \\
18 & $1.19 \mathrm{E}-01$ & $1.37 \mathrm{E}-01$ \\
21 & $1.39 \mathrm{E}-01$ & $1.58 \mathrm{E}-01$ \\
24 & $1.59 \mathrm{E}-01$ & $1.79 \mathrm{E}-01$ \\
27 & $1.79 \mathrm{E}-01$ & $2.00 \mathrm{E}-0 \mathrm{I}$ \\
30 & $1.99 \mathrm{E}-01$ & $2.21 \mathrm{E}-01$ \\
33 & $6.21 \mathrm{E}-02$ & $2.42 \mathrm{E}-01$ \\
36 & $6.77 \mathrm{E}-02$ & $6.77 \mathrm{E}-02$ \\
39 & $7.34 \mathrm{E}-02$ & $7.88 \mathrm{E}-02$ \\
42 & $2.63 \mathrm{E}-02$ & $3.22 \mathrm{E}-02$ \\
45 & $2.81 \mathrm{E}-02$ & $2.55 \mathrm{E}-02$ \\
48 & $3.01 \mathrm{E}-02$ & $3.22 \mathrm{E}-02$ \\
51 & $3.19 \mathrm{E}-02$ & $3.05 \mathrm{E}-02$ \\
54 & $1.69 \mathrm{E}-02$ & $2.11 \mathrm{E}-02$ \\
57 & $1.79 \mathrm{E}-02$ & $1.89 \mathrm{E}-02$ \\
60 & $1.88 \mathrm{E}-02$ & $1.78 \mathrm{E}-02$ \\
\hline
\end{tabular}


Table 9 Predictive and experimental values of E-Coli concentration at different time

\begin{tabular}{|c|c|c|}
\hline Time [T] & $\begin{array}{l}\text { Predictive values of } \\
\text { E-coli conc. [Mg/L] }\end{array}$ & $\begin{array}{l}\text { Experimental values of } \\
\text { E-Coli conc. }[\mathrm{Mg} / \mathrm{L}]\end{array}$ \\
\hline 10 & 2.34E-04 & 0.0063 \\
\hline 20 & $9.23 \mathrm{E}-03$ & 0.0116 \\
\hline 30 & 3.17E-02 & 0.0209 \\
\hline 40 & $5.63 \mathrm{E}-02$ & 0.0342 \\
\hline 50 & 5.87E-02 & 0.0515 \\
\hline 60 & 8.46E-02 & 0.0728 \\
\hline 70 & I.I5E-0। & 0.0981 \\
\hline 80 & |.50E-0| & 0.1274 \\
\hline 90 & I.90E-0| & 0.1607 \\
\hline 100 & $2.34 \mathrm{E}-0 \mathrm{I}$ & 0.198 \\
\hline 110 & 2.84E-0I & 0.2393 \\
\hline 120 & 3.38E-0I & 0.2846 \\
\hline 130 & 3.97E-0I & 0.3339 \\
\hline 140 & $4.60 \mathrm{E}-0 \mathrm{I}$ & 0.3872 \\
\hline 150 & $5.28 \mathrm{E}-0 \mathrm{I}$ & 0.4445 \\
\hline 160 & $6.00 \mathrm{E}-0 \mathrm{I}$ & 0.5058 \\
\hline 170 & 6.79E-0I & $0.57 \mid I$ \\
\hline 180 & 7.6IE-0I & 0.6404 \\
\hline 190 & 8.48E-0I & $0.7 \mid 37$ \\
\hline 200 & 9.39E-0। & 0.791 \\
\hline
\end{tabular}

Table 10 Predictive and experimental Values of E-Coli concentration at different depth

\begin{tabular}{|c|c|c|}
\hline Depth [M] & $\begin{array}{l}\text { Predictive values of } \\
\text { E-Coli conc. [Mg/L] }\end{array}$ & $\begin{array}{l}\text { Experimental values of } \\
\text { E-Coli conc. }[\mathrm{Mg} / \mathrm{L}]\end{array}$ \\
\hline 3 & 4.85E-05 & 0.000115858 \\
\hline 6 & I.93E-04 & 0.000260602 \\
\hline 9 & 4.35E-04 & 0.000354406 \\
\hline 12 & 7.74E-04 & 0.000406666 \\
\hline 15 & I.2IE-04 & 0.000426 \\
\hline 18 & I.74E-04 & 0.00042025 \\
\hline 21 & 2.37E-04 & 0.000396478 \\
\hline 24 & 3.09E-04 & 0.00036097 \\
\hline 27 & $3.92 \mathrm{E}-04$ & 0.000319234 \\
\hline 30 & $4.84 \mathrm{E}-04$ & 0.000276 \\
\hline 33 & 5.59E-05 & 0.000235222 \\
\hline 36 & $6.65 \mathrm{E}-05$ & 0.000200074 \\
\hline 39 & 7.8IE-05 & 0.000172954 \\
\hline 42 & 9.05E-05 & 0.000155482 \\
\hline 45 & I.06E-06 & $0.000 \mid 485$ \\
\hline 48 & I.I8E-06 & 0.000152074 \\
\hline 51 & I.34E-06 & 0.00016549 \\
\hline 54 & I.49E-06 & 0.000187258 \\
\hline 57 & I.66E-06 & 0.00021511 \\
\hline 60 & I.84E-06 & 0.000246 \\
\hline
\end{tabular}

\section{Conclusion}

The study has express the behavior of the system in terms of deposition under variation of permeability and void ratio in E-coli transport, the litho structure in the study environment express heterogeneous deposition under the influences of heterogeneous void ratio in sand grave formation, such condition were observed to pressure the transport behaviors of E-coli in sand grave depositions, exponential and fluctuation were experienced reflecting the litho structure of the predominant sand gravel deposition, the contaminant were found to pressure in transport process to Phreatic depositions, the study observed variation of micronutrient in different deposition, these are experienced in aquitard and unconfined deposition in Phreatic regions, the study centered more on time of transport under these lithology in the study environment, these condition implies that time and structural setting determined rapid rate of transport to Phreatic beds, these expression detailed the behavior of the transport system in sand gravel region of the study area. Other studies have base more on the depth of the formation, but time in relation to structural depositions has not monitored in detail, this study express the simulation of transport time more than that depth of the transport process, the simulation defined the system process of void ratios in heterogeneous condition, it also express the void ratio heterogeneous setting in sand gravel depositions, simulation developed some high percentage of favorable fits. The study has predicted time relationship with heterogeneous setting of void ratios in sand gravel formation.

\section{Acknowledgements}

None.

\section{Conflict of interest}

Authors declare there is no conflict of interest in publishing the article.

\section{References}

1. Arnold JG, Fohrer N. SWAT2000: current capabilities and research opportunities in applied watershed modelling. Hydrological Processes. 2005; 19:563-572.

2. Arnold JG, Srinivasan R, Muttiah RS, et al. Large area hydrologic modeling and assessment part i: model development. Journal of the American water resources association. 1998;34(10):73-89.

3. Pohlert T, Huisman JA, Breuer L, et al. Modelling of point and nonpoint source pollution of nitrate with SWAT in the river Dill, Germany. Advances in Geosciences. 2005;5:7-12.

4. Baffaut C, Benson VW. A Bacteria TMDL for Shoal Creek Using Swat Modeling and DNA Source Tracking. In: Total Maximum Daily Load (TMDL) Environmental Regulations II. ASAE Conference Proceedings, Albuquerque, New Mexico, editor A Saleh; 2003. p. 35-40

5. Guber AK, Pachepsky YA, Sadeghi AM. Evaluating uncertainty in E. coli retention in vegetated filter strips in locations selected with SWAT simulations. in ASABE, editor. Watershed Management to Meet Water Quality and TMDLS. San Antonio, Texas; 2007.p. 286-293.

6. Parajuli P, Mankin KR, Barnes PL. New methods in modeling sourcespecific bacteria at watershed scale using SWAT. In: Watershed Management to meet Water Quality Standards and TMDLs (Total Maximum Daily Load) Proceedings. ASABE 830 Publication No. 701P0207. St. Joseph, MI: ASABE; 2007.

7. Morgane Bougeard, Jean-Claude Le Saux, Nicolas Pérenne Monique Pommepuy. Modeling of Escherichia coli Fluxes on a catchment and the impact on coastal water and shellfish quality. Journal American water resources association. 2011;47(2):P350-366. 
8. Parajuli P. SWAT bacteria sub-model evaluation and application - an abstract of a dissertation. Department of Biological and Agricultural Engineering, College of Engineering, Manhattan, Kansas: Kansas State University; 2007. p. x-212.

9. Riou P, Le Saux JC, Dumas F, et al. Microbial impact of small tributaries on water and shellfish quality in shallow coastal areas. Water Research. 2007;41(12):2774-2786.

10. Fiandrino AY, Martin P, Got JL, et al. Bacterial contamination of Mediterranean coastal seawater as affected by riverine inputs: simulation approach applied to a shellfish breeding area (Thau lagoon, France). Water Research. 2003;37(8):1711-1722.
11. Hooda PS, Edwards AC, Anderson HA, et al. A review of water quality concerns in livestock farming areas. The Science of the Total Environment. 2000;250(1-3):143-167.

12. Parajuli P, Mankin KR, Barnes PL. Source specific fecal bacteria modeling using soil and water assessment tool model. Bioresource Technology. 2009;100(2):953-963. 